\title{
Peranan Logoterapi terhadap Pencapaian Makna Hidup Wanita Dewasa Awal (Studi pada Wanita Dewasa Awal yang Terdiagnosa HIV karena Tertular Suami)
}

\author{
Shinta Utami ${ }^{1}$, Samsunuwiyati Mar'at ${ }^{2}$, Denrich Suryadi ${ }^{3}$ \\ ${ }^{1}$ Program Studi Magister Psikologi, Universitas Tarumanagara Jakarta \\ Email: shinta.utamii@yahoo.co.id \\ ${ }^{2}$ Program Studi Magister Psikologi, Universitas Tarumanagara Jakarta \\ Email: samsunuwiyatimarat@yahoo.com \\ ${ }^{3}$ Program Studi Magister Psikologi, Universitas Tarumanagara Jakarta \\ Email: angiedenrich@yahoo.com
}

\begin{abstract}
ABSTRAK
Penularan virus HIV yang salah satunya melalui hubungan seksual risiko tinggi semakin meningkatkan penularan HIV dari individu positif ke individu negatif. Ketika hal tersebut terjadi pada istri yang positif HIV karena tertular suami, akan muncul berbagai ketakutan yang semakin memperburuk kondisi istri, seperti stigma masyarakat dan kekhawatiran terhadap anak-anak yang juga akan tertular HIV. Ketidakmampuan dalam menghadapi masalah terkait status positif HIV membuat para istri akan semakin tidak mampu menilai hidup mereka berharga sehingga makna hidup mereka menghilang. Tujuan penelitian ini adalah untuk mengetahui peranan logoterapi dalam pencapaian makna hidup wanita dewasa awal yang terdiagnosa HIV karena tertular suami. Terdapat tiga partisipan penelitian dan memiliki makna hidup yang rendah berdasarkan alat ukur TaruMiLS (Tarumanagara Meaning in Life Scale) yang dikembangkan oleh Suyasa dengan total 62 item. Berdasarkan hasil intervensi logoterapi yang diberikan selama 11 sesi, terjadi perubahan antara pretest dan posttest yang menunjukkan bahwa logoterapi berhasil membantu partisipan untuk mencapai makna hidup yang lebih positif dengan kondisi status positif HIV mereka saat ini.
\end{abstract}

Kata Kunci: logoterapi, makna hidup, wanita dewasa awal, HIV.

\section{PENDAHULUAN}

HIV dan AIDS merupakan istilah yang sering masyarakat gunakan untuk merujuk jenis penyakit yang sama yaitu penyakit yang mematikan bagi siapa saja yang menderitanya. Namunsebenarnya, antara HIV dan AIDS memiliki arti yang berbeda. Menurut WHO (Yayasan Spiritia, 2015) HIV atau Human Immunodeficiency Virus merupakan sebuah virus yang menyerang dan merusak fungsi sistem kekebalan tubuh manusia sehingga tubuh manusia lebih rentan terhadap penyakit. Virus yang sudah masuk dalam tubuh manusia akan terus berkembang dan semakin menurunkan sistem kekebalan tubuh menyebabkan manusia yang terkena HIV membutuhkan obat untuk melambatkan pertumbuhan virus, yang disebut dengan obat antiretroviral (ARV).Bagi ODHA (Orang dengan HIV/AIDS) yang tidak meminum ARV, akan menyebabkan sistem kekebalan tubuh semakin menurun dan memudahkan penyakit/infeksi untuk berkembang. Ketika satu atau lebih infeksi-infeksi oportunistik tersebut muncul, maka ODHA sudah memasuki tahap AIDS (Acquired Immunodeficiency Syndrome) sehingga AIDS dapat diartikan sebagai kumpulan gejala penyakit yang mematikan akibat menurunnya sistem kekebalan tubuh manusia.

Di Indonesia, penderita HIV menunjukkan kecenderungan peningkatan dari tahun ke tahun sejak kasus HIV pertama kali ditemukan di Indonesia, yaitu dari 859 kasus di tahun 1987 - 2005 menjadi 22.869 kasus di tahun 2014dengan peringkat teratas diderita oleh masyarakat usia produktif (25-49 tahun) yaitu mencapai 16.421 kasus (Ditjen PP \& Kemenkes, 2014). Terdapat beberapa faktor yang membuat jumlah penderita HIV terus meningkat tiap tahunnya, di antaranya adalah perilaku berisiko tinggi terkait hubungan seksual yang tidak aman dengan berganti-ganti pasangan serta tidak menggunakan kondom pada individu dengan tingkat risiko 
tinggi, penggunaan jarum suntik secara bergantian, transfusi darah tanpa pemeriksaan HIV atas darah yang diterima, hingga penularan dari ibu ke anak melalui proses melahirkan ataupun pemberian air susu ibu (Yayasan Spiritia, 2003).Menurut Ditjen PP dan Kemenkes (2014), di antara faktor risiko tersebut, faktor risiko tertinggi adalah melalui hubungan seksual pada masyarakat heteroseksual terhadap penularan HIV dengan jumlah kasus sebanyak 8.922 di tahun 2014. Perilaku seksual berisiko pada masyarakat heteroseksual dilatarbelakangi oleh perilaku yang berganti-ganti pasangan seksual dan tanpa mengetahui bahwa pasangan seksualnya tersebut sudah positif HIV serta tidak menggunakan kondom dalam berhubungan seksual menjadi jalan bagi HIV menularkan individu yang negatif HIV karena virus tersebut langsung menular melalui sperma dan cairan vagina(Madyan, 2009).

Priohutomo (dikutip dalam Anugerah, 2015), selaku Direktur Jenderal Pengendalian Penyakit Menular menyatakan bahwa sebanyak 6,7 juta pria di Indonesia merupakan konsumen dari tempat-tempat prostitusi dan sekitar 4,9 juta wanita menikah dengan pria berisiko tinggi. Fenomena tersebut menunjukkan bahwa wanita yang sudah menikah menjadi rentan terhadap penularan HIV terutama jika wanita tersebut maupun pasangannya tidak terlalu memahami HIV yang dapat menular melalui hubungan seksual. Priohutomo (dikutip dalam Anugerah, 2015) lebih lanjut menambahkan bahwa kasus yang ditemukan pada kalangan ibu rumah tangga banyak yang tidak lagi dalam tahap HIV, melainkan AIDS sebagai akibat kurangnya pengetahuan terkait HIV/AIDS. Pernyataan tersebut sesuai dengan data Ditjen PP dan Kemenkes (2014) sejak tahun 1987 hingga September 2014 menunjukkan bahwa ibu rumah tangga menjadi penderita AIDS tertinggi yaitu 6.539 kasus dari total 30.598 kasus.

Bagi individu yang mengetahui status positif HIV, terutama pada wanita yang sudah menikah, tentu dampak yang dirasakan akan lebih besar secara psikologis. Hal ini berkaitan dengan rasa khawatir atas kemungkinan anak-anak mereka juga tertular HIV, baik karena penularan melalui proses kelahiran normal ataupun karena pemberian air susu ibu kepada bayi-bayi mereka (Yayasan Spiritia, 2003). Selain itu, stigma terkait tindakan amoral yang diberikan masyarakat terkait wanita yang terkena HIV semakin memberatkan kondisi psikologis mereka, sehingga masyarakat cenderung menjauhi mereka. Menurut Emlet (dikutipdalam Vance \& Denham, 2008), wanita dengan HIV/AIDS memiliki tingkat dijauhi, disalahkan, serta diskriminasi oleh masyarakat lebih tinggi dibandingkan dengan laki-laki. Diskriminasi tersebut dapat muncul mulai dari lingkungan masyarakat terkecil, yaitu keluarga, teman, hingga lingkungan komunitas mereka.

Kecenderungan isolasi diri, kecemasan, depresi, maupun mengasingkan diri tidak hanya merupakan bentuk dari perasaan tidak berdaya dari situasi yang sedang dialami saat ini, tetapi juga bentuk dari hilangnya makna hidup sehingga individu cenderung menjalani hidup tanpa tujuan dan arah (Audet, Wagner, \& Wallston, 2015). Kondisi positif HIV dianggap sebagai kejadian tragis yang membuat makna hidup menghilang. Meskipun individu tidak dapat menghindar dari situasi yang tidak menyenangkan atau tragis, akan tetapi individu dapat bersikap adaptif dalam menghadapi situasi yang sedang terjadi. Hal tersebutlah yang dapat dilakukan bagi para istri yang mengetahui status kesehatannya saat ini yaitu positif HIV. Namun, yang menjadi kendala adalah ketidakmampuan mereka untuk mencari makna atas situasi yang sedang dihadapinya saat ini.

Dalam mencapai makna hidup, Frankl (dikutip dalam Bastaman, 2007) memandang logoterapi sebagai teknik yang dapat membantu individu untuk memahami potensi yang dimiliki meskipun dalam situasi yang kurang menguntungkan yang selama ini tidak disadari, terhambat, maupun terlupakan serta memanfaatkan potensi tersebut sehingga muncul kembali semangat dan tujuan 
hidup serta meningkatkan kualitas hidup yang lebih bermakna. Situasi yang kurang menguntungkan yang dialami oleh individu mampu menyebabkan hilangnya tujuan hidup.

Di Indonesia, logoterapi diadaptasi oleh Bastaman (2007) dengan tetap berlandaskan logoterapi dari Frankl yang disebut dengan Panca Cara Temuan Makna. Penelitian-penelitian sebelumnya yang menggunakan logoterapi adaptasi Bastaman adalah Triwardhany (2015) yang menunjukkan bahwa logoterapi yang menerapkan Panca Cara Temuan Makna berhasil meningkatkan selfesteem pada pria dewasa yang terinfeksi HIV. Selain itu, Chandra (2012) melakukan penelitian dengan menggunakan logoterapi dengan adaptasi Bastaman yang hasilnya adalah logoterapi efektif dalam mengatasi loneliness pada perempuan lansia.

Hasil dari penelitian-penelitian di atas menunjukkan bahwa logoterapi memiliki peran yang positif terhadap makna hidup para partisipan penelitian. Namun berdasarkan kajian literatur yang dilakukan, peneliti belum menemukan penelitian terkait logoterapi untuk menangani pasien HIV khususnya wanita yang tertular dari suami. Sementara, makna hidup menjadi sangat penting bagi pasien HIV untuk tetap membuat mereka bertanggungjawab terhadap hidup dengan secara rutin meminum obat ARV, menyadari kemampuan diri yang selama ini tidak disadari dan menemukan kembali tujuan hidup mereka sehingga mereka tetap berdaya dengan status kesehatannya saat ini. Atas dasar alasan-alasan tersebut, maka peneliti melakukan penelitian terkait peranan logoterapi terhadap pencapaian makna hidup terhadap wanita dengan HIV positif yang tertular dari suami.

\section{METODE}

Desain penelitian yang digunakan adalah quasi-experimental dengan tipe one group pretest posttest design, yaitu dengan menggunakan satu kelompok saja tanpa adanya kelompok pembanding serta dilakukan pengukuran sebelum dan sesudah diberikan intervensi untuk melihat efek pemberian intervensi (Shaughnessy, Zechmeister, \& Zechmeister, 2015). Sementara dalam menentukan partisipan, peneliti menggunakan teknik nonprobability sampling dengan metode purposive sampling, yaitu metode pengambilan sampel secara sengaja sesuai dengan karakteristik sampel yang diperlukan. Karakteristik partisipan dalam penelitian ini adalah (a) perempuan dewasa awal (20-40 tahun), (b) sudah menikah, (c) positif HIV karena tertular suami, (d) memiliki persepsi negatif terhadap makna hidup yang terlihat dari hasil alat ukur makna hidup TaruMiLS (Tarumanagara Meaning in Life Scale) yang dikembangkan oleh Suyasa (2008). Selain itu, terdapat beberapa instrumen yang diberikan kepada para partisipan, antara lain infomed consent, tes inteligensi CFIT 3A, dan tes minat RMIB Wanita. Berdasarkan kriteria tersebut, maka terdapat tiga partisipan yang terlibat dalam penelitian ini.

Tabel 1. Data biografi partisipan penelitian

\begin{tabular}{lccc}
\hline \multicolumn{1}{c}{ Keterangan } & Partisipan 1 & Partisipan 2 & Partisipan 3 \\
\hline Nama & Z & W & N \\
Usia & 39 Tahun & 29 Tahun & 21 Tahun \\
Status Pernikahan & Bercerai & Menikah & Menikah \\
Anak & 3 & - & 2 \\
Pendidikan & SMA & SMA & SMA \\
Agama & Islam & Islam & Islam \\
Tahun Terdiagnosa HIV & 2008 & 2012 & 2016 \\
Pekerjaan & Berdagang & IRT & IRT \\
Tingkat Inteligensi & 96 (rata-rata) & 96 (rata-rata) & 100 (rata-rata) \\
Minat & Practical & Practical & Practical \\
\hline
\end{tabular}

Penelitian dilakukan di tiga tempat, yaitu di kantor RW daerah Jakarta Utara, Rumah Sakit X dan Universitas Y. Pada lokasi penelitian di kantor RW merupakan lokasi utama bagi peneliti dan 
partisipan melakukan pengambilan data dan pelaksanaan intervensi. Sementara Rumah Sakit X dan Universitas Y merupakan lokasi kegiatan KDS (Kelompok Dukungan Sebaya) yang diikuti oleh para partisipan. Pada kedua lokasi tersebut, peneliti berkesempatan untuk hadir guna memperoleh data tambahan dari wawancara maupun observasi para partisipan penelitian terkait kegiatan yang diikuti oleh mereka.

\section{HASIL}

Seluruh partisipan mengikuti intervensi sesuai dengan rancangan intervensi yang telah ditetapkan pada penelitian ini, yaitu 11 sesi intervensi berdasarkan logoterapi hasil adaptasi Bastaman yang meliputi Pemahaman Diri, Berpikir dan Bertindak Positif, Pengakraban Hubungan, Pendalaman Catur Nilai, serta Ibadah. Selain itu, para partisipan penelitian akan mengisi TaruMiLS yang mengukur pencapaian makna hidup pada saat sebelum dan sesudah keseluruhan intervensi dilakukan oleh peneliti.Alat ukur TaruMiLS menggunakan skala $1-7$ sehingga nilai tengahnya adalah 4 . Nilai tengah tersebut akan menjadi nilai batas antara skor kategori tinggi dan kategori rendah. Pada dimensi spiritual menunjukkan bahwa semakin tinggi skor partisipan maka semakin individu positif dalam memersepsikan hidup mereka sebagai sesuatu yang memiliki arti, berharga, diwarnai dengan cinta, dan sebagainya. Sama halnya dengan dimensi materialism, semakin tinggi skor partisipan maka semakin individu memersepsikan tujuan hidup adalah untuk mengumpulkan barang-barang, memiliki banyak teman atau untuk mengumpulkan sesuatu. Sementara pada dimensi problem, semakin tinggi skor partisipan maka semakin individu memersepsikan hidup mereka sebagai sesuatu yang berat, sulit, penuh dengan rintangan, dan sebagainya.

\section{Partisipan pertama (Z)}

Tabel 2. Hasil pretest dan post-test makna hidup partisipan pertama

\begin{tabular}{ccccc}
\hline & \multirow{2}{*}{ Rata-rata } & \multicolumn{2}{c}{ Rata-rataTiap Dimensi Makna Hidup } \\
& & Spiritual & Problem & Materialism \\
\hline Pretest & 3.98 (rendah) & 3.83 (rendah) & 5.40 (tinggi) & 3.75 (rendah) \\
Posttest & 4.63 (tinggi) & 4.83 (tinggi) & 3.80 (rendah) & 4.25 (tinggi) \\
\hline
\end{tabular}

Sebelum intervensi logoterapi diberikan, $\mathrm{Z}$ menganggap bahwa hidupnya banyak mengalami masalah terutama setelah mengetahui kondisi positif HIV yang tidak hanya dialami olehnya, tetapi juga dialami oleh anak terakhirnya, yaitu RH. Selain itu, kondisi RH yang sudah memasuki terapi ARV lini dua membuat reaksi psikologis $\mathrm{Z}$ cenderung menyalahkan diri sendiri. Hal ini dikarenakan ia memiliki tanggung jawab dan kendali agar $\mathrm{RH}$ minum obat teratur dan tepat waktu. Beban Z semakin bertambah ketika RH mengatakan bahwa ia bosan minum obat dan mulai menanyakan penyakit yang diderita sehingga membuatnya harus selalu minum obat. Atas kondisi $\mathrm{Z}$ tersebut, maka logoterapi diberikan sebagai intervensi untuk $\mathrm{Z}$ dengan tujuan agar $\mathrm{Z}$ menemukan makna hidup sehingga ia mampu menjalani hidup dengan tujuan yang lebih jelas dan positif meskipun berada dalam kondisi yang tidak menguntungkan dan tidak lagi dapat ia ubah, yaitu terkait kondisi positif HIV yang dialami oleh ia dan anaknya.

Setelah diberikan intervensi logoterapi, hasil posttest menunjukkan bahwa pemberian intervensi berefek terhadap persepsi $\mathrm{Z}$ mengenai makna hidupnya saat ini yang cenderung ke arah yang lebih positif dibandingkan dengan sebelum diberikan intervensi. Pada dimensi spiritual, $\mathrm{Z}$ memersepsikan hidupnya sebagai sesuatu yang memiliki arti yang dapat dilihat saat ia menjalani tiap sesi intervensi dan semakin menyadari bahwa hidupnya juga memiliki arti bagi orang lain, tidak hanya untuk anak-anak atau keluarga terdekat, tetapi juga untuk ODHA lain. Pada dimensi problem, $\mathrm{Z}$ meyakini bahwa ia akan mampu melalui masa sulit dalam hidupnya saat ini, yaitu RH yang masuk ke pengobatan lini dua seperti pada masa sulit yang telah ia alami sebelumnya 
terkait KDRT yang dialami oleh suami dan ketika mengetahui ia dan RH positif HIV. Terakhir, pada dimensi materialism menunjukkan bahwa tujuan utama hidup $\mathrm{Z}$ adalah anak-anaknya sehingga ia dalam melakukan suatu hal cenderung dikarenakan anak-anak, seperti rutinitasnya dalam berdagang didasari oleh dorongan $\mathrm{Z}$ untuk dapat memenuhi kebutuhan anak anak. Selain itu, usaha $\mathrm{Z}$ untuk tetap patuh minum obat juga didasari oleh anak-anak yang harus tetap ia jaga dan rawat sehingga tetap memacunya untuk tetap menjaga kesehatan dengan teratur minum ARV. Selain itu, penghayatan $\mathrm{Z}$ terhadap kehidupannya setelah pemberian logoterapi adalah memandang bahwa hidupnya kini tidak hanya berarti untuk diri sendiri, namun juga berarti bagi orang lain, terutama anak-anaknya yang masih membutuhkan perhatian dan kasih sayangnya.

\section{Partisipan kedua (W)}

Tabel 3. Hasil pretest dan post-test makna hidup partisipan kedua

\begin{tabular}{ccccc}
\hline & \multirow{2}{*}{ Rata-rata } & \multicolumn{2}{c}{ Rata-rata Tiap Dimensi Makna Hidup } \\
& & Spiritual & Problem & Materialism \\
\hline Pretest & 3.95 (rendah) & 3.71 (rendah) & 5.20 (tinggi) & 3.75 (rendah) \\
Posttest & 4.45 (tinggi) & 4.63 (tinggi) & 3.60 (rendah) & 4.50 (tinggi) \\
\hline
\end{tabular}

Kondisi W saat ini yang sudah tidak memiliki anak menganggap bahwa hidupnya sekarang terasa sepi. W dan suami ingin memiliki anak namun keduanya masih merasa takut jika anaknya kelak akan tertular HIV. Saat ini, perilaku yang muncul dalam menjalani kehidupan sehari-hari adalah bangun tidur cenderung siang karena menganggap tidak ada yang perlu membuatnya bangun pagi, yaitu sudah tidak memiliki anak. Selain itu, W pun menganggap bahwa suami tidak masalah dengan perilakunya saat ini yang sering bangun siang. W menyatakan bahwa perilakunya saat ini sangat berbeda dengan perilakunya dulu saat masih memiliki anak. Saat itu W selalu bangun pagi karena mendekati waktu subuh anak selalu sudah bangun dan ia akan selalu sibuk sepanjang hari untuk mengurus kebutuhan anak dan suaminya. Selain itu, W yang saat ini tidak diizinkan oleh suami untuk melakukan kegiatan di luar rumah membuatnya menganggap hidupnya saat ini sangat membosankan dengan rutinitas yang selalu berulang. Perilaku dan perasaan yang muncul pada $\mathrm{W}$ dalam menjalani kesehariannya tersebut sudah menunjukkan bahwa adanya kecenderungan neurosis noogenik.

Setelah diberikan intervensi logoterapi, hasil posttest makna hidup menunjukkan bahwa intervensi yang dilakukan memiliki efek positif terhadap persepsi $\mathrm{W}$ terkait makna hidupnya saat ini, yaitu cenderung memandang hidup lebih positif dibandingkan dengan sebelum diberikan intervensi. Pada dimensi spiritual, W menyadari bahwa ketidakhadiran anak memang membuatnya sedih dan merasa hampa dalam menjalani hidup, namun kehadiran orang-orang terdekat juga dapat membuat hidupnya terasa lebih berarti, yaitu seperti adanya suami yang saling memberikan dukungan selama ini dalam pengobatan ARV dan kehidupan rumah tangga mereka tetap dapat berjalan dengan baik meskipun saat ini memutuskan untuk tidak memiliki anak. W yang semakin menyadari bahwa kehadiran keluarga yang selalu memberikan dukungan yang tidak hanya saat ia baru mengetahui status positif saja, tetapi hingga saat ini, kembali memunculkan rasa syukur atas hidupnya saat ini di tengah kondisi status positif yang sudah tidak dapat ia ubah. Pada dimensi problem, W cenderung memersepsikan hidupnya sebagai sesuatu yang memiliki rintangan namun dapat ia atasi. Jika dilihat selama intervensi berlangsung, $\mathrm{W}$ menyadari bahwa ia telah menghadapi situasi-situasi yang lebih sulit dibandingkan dengan kondisi saat ini yang tidak memiliki anak. W sudah berhasil melalui kondisi menyedihkan ketika didiagnosa positif HIV dan perekonomian semakin sulit karena baik W maupun suami mengalami penurunan secara fisik. Oleh karena itu, $\mathrm{W}$ memandang bahwa kondisi saat ini juga dapat ia hadapi karena kondisi sebelumnya pun sudah dapat ia hadapi. 
Terakhir, pada dimensi materialism, W menganggap bahwa tujuan utama hidupnya adalah untuk berbakti dengan suaminya. Hal ini dikarenakan saat ini orang yang paling dekat dengan W adalah suami dan menurutnya sudah seharusnya seorang istri berbakti dengan suami. Bentuk nyata dari berbakti dengan suami adalah dengan menuruti perkataan suami dan tetap berusaha untuk menjadi citra diri idaman W, yaitu belajar memasak untuk suami. Selain itu, penghayatan W terhadap kehidupannya setelah pemberian logoterapi adalah memandang bahwa hidupnya juga memiliki arti bagi orang lain, yaitu suaminya. Terlebih lagi $\mathrm{W}$ menganggap bahwa keduanya saling menguatkan sehingga ia memandang bahwa hidupnya juga memiliki arti untuk kehidupan suaminya.

\section{Partisipan Ketiga (N)}

Tabel 4. Hasil pretest dan post-test makna hidup partisipan ketiga

\begin{tabular}{ccccc}
\hline & \multirow{2}{*}{ Rata-rata } & \multicolumn{2}{c}{ Rata-rataTiap Dimensi Makna Hidup } \\
& & Spiritual & Problem & Materialism \\
\hline Pretest & 3.76 (rendah) & 3.44 (rendah) & 5.50 (tinggi) & 3.25 (rendah) \\
Posttest & 4.29 (tinggi) & 4.33 (tinggi) & 3.90 (rendah) & 4.75 (tinggi) \\
\hline
\end{tabular}

$\mathrm{N}$ yang belum satu tahun didiagnosa positif HIV, masih menunjukkan sikap tidak terima atas status positifnya saat ini. Dalam bersikap, $\mathrm{N}$ cenderung mengatakan bahwa ia sudah menerima dengan status positifnya saat ini. Akan tetapi, ketika $\mathrm{N}$ bertemu dengan orang lain yang memberikan rasa simpati dan mengatakan kepada $\mathrm{N}$ untuk bersabar atas kondisinya saat ini, $\mathrm{N}$ cenderung mengatakan bahwa orang lain akan dengan mudah berkata sabar namun akan sulit menerima jika mengalami secara langsung kondisi positif HIV. Hal tersebut menunjukkan bahwa $\mathrm{N}$ masih merasa sulit untuk menerima kondisi status positifnya saat ini.

Saat ini, muncul berbagai hal yang $\mathrm{N}$ anggap sebagai ketakutannya setelah mengetahui status positif, yaitu ketakutan akan ditinggalkan suami karena saat ini suami berstatus negatif HIV dan juga ketakutan terhadap anak terakhir $\mathrm{N}$ akan tertular HIV karena proses kelahirannya yang normal. Tidak hanya dua hal itu, kondisi tubuh $\mathrm{N}$ yang cenderung mudah lelah membuatnya tidak dapat bekerja dan kebutuhan sehari-hari untuk keluarga cenderung kurang tercukupi karena pendapatan hanya dari suami $\mathrm{N}$ saja. Bagi $\mathrm{N}$, hal tersebut merupakan hal yang besar karena jika suami meninggalkannya, $\mathrm{N}$ akan berpikir ulang untuk kembali menikah karena akan jarang pria yang ingin menikahi wanita yang positif HIV. Sementara terkait anaknya yang masih berumur delapan bulan, $\mathrm{Z}$ merasa tidak dapat bayangkan jika anaknya positif dan harus minum obat seumur hidup. Ketakutan-ketakutan yang $\mathrm{N}$ alami menjadikannya cenderung berserah diri dengan keadaan yang akan terjadi, yaitu seperti berkali-kali menyatakan kepada suami bahwa ia rela jika diceraikan. Meskipun berkata demikian, selama sesi berlangsung $\mathrm{N}$ menyatakan bahwa ia pun tidak ingin bila diceraikan oleh suami. Perilaku dan perasaan yang muncul pada $\mathrm{N}$ menunjukkan bahwa telah munculnya neurosis noogenik pada $\mathrm{N}$.

Setelah diberikan intervensi logoterapi, hasil posttest menunjukkan bahwa intervensi yang dilakukan memiliki efek positif terhadap persepsi $\mathrm{N}$ terkait makna hidupnya saat ini, yaitu cenderung memandang hidup lebih positif dibandingkan dengan sebelum diberikan intervensi. Makna hidup $\mathrm{N}$ yang berada dalam kategori tinggi dapat dijelaskan lebih lanjut dengan melihat dimensi-dimensi pada alat ukur TaruMiLS. Pada dimensi spiritual, N memersepsikan hidupnya sebagai sesuatu yang memiliki arti, berharga dan diwarnai dengan cinta yang terbentuk ketika $\mathrm{N}$ menjalani tiap sesi intervensi dan semakin menyadari meskipun ketakutan tersebut masih ada, namun ia menganggap bahwa seharusnya saat ini ia mampu bersyukur dengan keadaan sekarang, yaitu suami masih mendampingi bahkan mengatakan untuk tidak akan meninggalkan $\mathrm{N}$ dan juga kondisi anak $\mathrm{N}$ yang masih terlihat baik dan tidak menunjukkan tanda-tanda terinfeksi HIV. 
Pada dimensi problem, $\mathrm{N}$ cenderung memersepsikan hidup sebagai suatu rintangan namun dapat ia jalani. $\mathrm{N}$ saat ini memang menganggap bahwa belum ada masalah yang lebih berat dibandingkan dengan mengetahui status positif. Namun, dengan mengetahui cerita para penderita HIV dan bertemu langsung dengan mereka, $\mathrm{N}$ cenderung merasa bersyukur bahwa kondisinya saat ini lebih baik dibandingkan dengan kondisi teman-teman ODHA yang lain. Hal tersebut memunculkan penghayatan yang lebih positif dibanding sebelumnya, yaitu keyakinan diri bahwa ia akan bisa melalui masa-masa saat ini.

Terakhir, pada dimensi materialism, $\mathrm{N}$ memiliki persepsi yang lebih positif dibandingkan sebelumnya. Jika sebelum pemberian intervensi $\mathrm{N}$ cenderung menganggap negatif seluruh orangorang terdekatnya, seperti suami dan ibu. Namun setelah pemberian intervensi, $\mathrm{N}$ mampu melihat sisi positif dari orang-orang terdekatnya berdasarkan pengalamannya dalam usaha untuk memperdalam hubungan dengan suami dan dengan ibu N. Selain itu, pemberian intervensi kepada $\mathrm{N}$ menjadikannya menyadari tujuan hidupnya saat ini, yaitu untuk bersama dengan orang-orang terdekat, terutama anak-anaknya yang juga menjadi semangat baginya agar tetap menjaga kondisi tubuh, yaitu dengan rutin meminum obat. Namun, penghayatan $\mathrm{N}$ terkait makna hidupnya untuk diri sendiri masih kurang terlihat secara jelas. Hal tersebut dikarenakan kondisi $\mathrm{N}$ yang masih denial terkait status HIV yang baru ia ketahui sehingga perasaan takut dan cemas masih mendominasi keadaannya saat ini.

Berdasarkan hasil penelitian tersebut, diketahui bahwa logoterapi dapat membantu partisipan mencapai makna hidup mereka di dalam situasi yang tidak dapat mereka ubah. Makna hidup ketiga partisipan setelah diberikan intervensi logoterapi berbeda-beda antara satu partisipan dengan partisipan yang lain. Jika pada partisipan $\mathrm{Z}$ dan $\mathrm{N}$ makna hidupnya terletak pada anakanaknya, namun berbeda dengan $\mathrm{W}$ yang menganggap bahwa makna hidupnya terletak pada suaminya. Perbedaan tersebut merupakan suatu hal yang wajar karena makna hidup setiap individu dapat saling berbeda satu sama lain. Hal ini sesuai dengan pernyataan Frankl (1984) bahwa makna hidup setiap orang bersifat unik dan pribadi sehingga suatu hal yang dianggap berarti oleh satu individu, belum tentu berarti bagi individu yang lain.

Bastaman (2007) menambahkan bahwa makna hidup tidak hanya bersifat unik dan pribadi, namun juga bersifat spesifik dan nyata sehingga makna hidup bukanlah sesuatu yang hanya dapat dibayangkan atau menjadi angan-angan bagi individu, namun sesuatu yang dapat dilakukan di kehidupan sehari-hari. Makna hidup tersebut selanjutnya akan menjadi pedoman dan arah bagi individu untuk menjalani kehidupan mereka. Di dalam penelitian ini, ketiga partisipan yang memersepsikan makna hidup mereka dengan adanya kehadiran orang lain tidak hanya sebatas menganggap makna hidup tersebut tanpa adanya bentuk nyata atas makna hidup tersebut, akan tetapi mereka juga mengikutinya dengan rencana atau usaha yang nyata untuk memaknai hidup mereka dengan tujuan yang jelas. Pada partisipan Z, bekerja dengan tetap menjaga kondisi fisik dan teratur meminum ARV merupakan usaha nyata untuk memaknai hidupnya agar tetap dapat menjadikan dirinya bermanfaat bagi anak-anaknya. Sementara W, membantu suami bekerja dengan cara bergantian menjaga counter handphone dan saling mendukung dalam pengobatan merupakan usaha yang nyata baginya untuk memaknai hidupnya bernilai untuk orang lain. Terakhir, usaha nyata $Z$ agar hidupnya memiliki arti bagi anakanaknya dengan tetap mempertahankan kondisi tubuhnya, yaitu dengan berusaha meminum obat secara teratur serta banyak mengikuti KDS (Kelompok Dukungan Sebaya) agar semakin banyak pengetahuan yang ia dapat terkait hidup sehat sebagai ODHA. Bagi N, jika ia sehat, maka ia akan semakin memiliki kesempatan yang besar untuk terus merawat anak-anaknya hingga mereka besar. 
Perbedaan lain yang muncul pada penelitian ini tidak hanya terkait makna hidup ketiga partisipan saja, namun juga terletak pada hasil pretest dan posttest yang mengukur makna hidup ketiga partisipan, yaitu TaruMiLS. Jika dilihat dari alat ukur tersebut, Z memiliki perubahan lebih besar dibandingkan kedua partisipan lainnya. Ada kemungkinan lama terdiagnosa positif HIV dan usia partisipan memiliki peranan lebih besar atas keberhasilan logoterapi untuk pencapaian makna hidup. Hal tersebut mengingat $\mathrm{Z}$ merupakan partisipan yang memiliki usia paling tua dan terdiagnosa HIV lebih lama dibandingkan dengan kedua partisipan penelitian lainnya. Selain itu, pada penelitian ini juga ditemukan bahwa di antara ketiga partisipan, hanya $\mathrm{N}$ yang masih belum menghayati kehidupannya bagi dirinya sendiri. Ada kemungkinan hal tersebut dikarenakan kondisinya yang baru mengetahui status HIV menjadikan sikap belum mampu menerima diri, rasa cemas dan ketakutan lebih mendominasi sehingga masih mengalami kesulitan dalam menghayati kebermaknaan hidupnya sendiri. Terkait temuan-temuan pada penelitian ini, maka masih perlu dilakukan penelitian lebih lanjut tentang hal tersebut.

Ketiga partisipan dalam penelitian ini tidak mendapatkan perilaku diskriminatif dari anggota keluarga terkait status positif HIV yang dialami oleh mereka. Keluarga justru tetap menjaga kerahasiaan status positif mereka serta memberikan dukungan dengan mencari informasi lebih jauh terkait HIV maupun membantu secara materi ketika mereka mengalami kesulitan ekonomi karena kondisi tubuh yang melemah di masa awal terapi obat ARV yang membuat penghasilan menurun. Menurut Emlet (dikutip dalam Vance \& Denham, 2008) dalam penelitiannya terkait wanita yang terdiagnosa HIV/AIDS karena berbagai faktor menunjukkan bahwa wanita HIV/AIDS memiliki tingkat dijauhi, disalahkan serta diskriminasi oleh lingkungan seperti keluarga, teman, hingga lingkungan komunitas mereka lebih tinggi dibandingkan dengan lakilaki. Terkait penelitian di atas, hal tersebut tidak terjadi pada ketiga partisipan penelitian. Keluarga partisipan cenderung memberikan dukungan dan lebih menyalahkan suami yang menjadi penyebab partisipan tertular HIV. Selain itu, diskriminasi dari teman atau tetangga terkait status positif HIV juga tidak terjadi pada ketiga partisipan penelitian karena ketiga partisipan memilih untuk tidak membuka status mereka ke lingkungan luar selain ke pihak-pihak yang penting untuk diberitahukan, seperti keluarga dan pihak medis. Alasan ketiga partisipan adalah karena ketidaksiapan mereka dalam menghadapi diskriminasi yang mungkin akan diterima jika membuka status positif HIV. Alasan tersebut sesuai dengan penelitian yang dilakukan oleh Crandall, Coleman, Vandewanter, Thacker, Bass \& Arnold (dikutip dalam Carr \& Gramling, 2004) bahwa wanita dengan HIV/AIDS lebih memilih untuk tidak membuka status ke orang lain dibandingkan harus menanggung konsekuensi berupa perilaku diskriminatif dari lingkungan dan hal tersebut yang membuat mereka cenderung mengalami kecemasan, depresi, dan mengasingkan diri dari lingkungan luar.

\section{KESIMPULAN DAN SARAN}

Berdasarkan hasil penelitian dan analisis, maka dapat disimpulkan bahwa hasil intervensi pada ketiga partisipan dengan menggunakan logoterapi berhasil membantu partisipan untuk mencapai makna hidup yang lebih positif terkait dengan kondisinya saat ini yang terdiagnosa positif HIV karena tertular suami. Kesimpulan tersebut didasari oleh data yang diolah secara kualitatif dan kuantitatif. Secara kualitatif, hasil dari intervensi logoterapi yang diberikan pada tiga partisipan menunjukkan bahwa mereka mampu memersepsikan kehidupannya semakin positif dibandingkan sebelum pemberian intervensi logoterapi sehingga semakin menyadari makna hidup mereka masing-masing.

Secara kuantitatif, hasil dari intervensi logoterapi pada ketiga partisipan terlihat dari hasil pretest dan posttest alat ukur makna hidup, yaitu TaruMiLS (Tarumanagara Meaning of Life Scale). Dari ketiga partisipan penelitian, $\mathrm{Z}$ memiliki perbedaan lebih besar antara pretest dan posttest 
setelah diberikan intervensi logoterapi dibandingkan dengan $\mathrm{W}$ dan $\mathrm{N}$, yaitu sebesar 0.65 sementara $\mathrm{W}$ sebesar 0.50 dan $\mathrm{N}$ sebesar 0.53 . Lebih lanjut lagi, tiga dimensi yang ada pada alat ukur TaruMiLSjuga menunjukkan perbedaan antara pretest dan posttest, yaitu (a) pada dimensi spiritual, sebelum diberikan intervensi ketiga partisipan berada dalam kategori rendah dan selanjutnya berada di kategori tinggi setelah diberikan intervensi. Hal ini menunjukkan bahwa ketiga partisipan semakin memersepsikan hidup mereka sebagai sesuatu yang berarti, berharga dan diwarnai dengan cinta. (b) pada dimensi problem, sebelum diberikan intervensi ketiga partisipan berada dalam kategori tinggi dan selanjutnya berada di kategori rendah setelah diberikan intervensi. Hal ini menunjukkan bahwa ketiga partisipan semakin memersepsikan kehidupan mereka sebagai sesuatu yang penuh dengan rintangan namun berkeyakinan pula bahwa mereka dapat melewati rintangan dalam kehidupan tersebut. Terakhir (c) pada dimensi materialism, sebelum diberikan intervensi ketiga partisipan berada dalam kategori rendah dan selanjutnya berada di kategori tinggi setelah diberikan intervensi. Hal ini menunjukkan bahwa ketiga partisipan memersepsikan tujuan hidup mereka adalah untuk memiliki sesuatu, baik memiliki banyak teman atau memiliki hal yang bersifat material.

Sumber-sumber nilai sebagai usaha untuk mencapai makna hidup telah diterapkan di dalam intervensi logoterapi, yaitu creative values (nilai-nilai kreatif), experiential values (nilai-nilai penghayatan), attitudinal values (nilai-nilai bersikap) dan hopeful values (nilai-nilai pengharapan). Keempat sumber pencapaian makna tersebut memiliki efek positif pada ketiga partisipan di setiap sesi yang dijalani. Berdasarkan intervensi yang telah dilakukan dengan didasari oleh nilai-nilai tersebut, ketiga partisipan menganggap bahwa makna hidup mereka terletak pada hadirnya orang terdekat di kehidupan mereka. Dengan adanya kehadiran orang terdekat, ketiga partisipan semakin menganggap diri mereka dibutuhkan oleh orang lain sehingga semakin memersepsikan bahwa kehidupan mereka adalah sesuatu yang penting. Sementara itu, penghayatan masing-masing partisipan terkait makna hidup mereka cenderung berbeda. Pada Z dan $\mathrm{W}$ menghayati kehidupan mereka memiliki arti dan dibutuhkan oleh orang lain, yaitu anakanak dan suami. Akan tetapi, penghayatan pribadi terhadap kehidupan yang dimiliki cenderung belum terbentuk pada $\mathrm{N}$. Hal ini dikarenakan $\mathrm{N}$ masih diliputi oleh kecemasan dan ketakutan terkait status HIV yang baru ia ketahui.

Saran bagi peneliti yang ingin meneliti lebih lanjut terkait peranan logoterapi terhadap pencapaian makna hidup wanita yang terdiagnosa HIV karena tertular suami dapat mempersempit kriteria partisipan penelitian, seperti menambahkan kriteria lama terdiagnosa HIV dan jarak terdiagnosa positif HIV tidak terlalu jauh antara satu partisipan dengan partisipan yang lain. Hal tersebut disarankan agar hasil penelitian dapat lebih digeneralisasi.

Tidak hanya terkait kriteria partisipan penelitian saja, penelitian selanjutnya juga dapat dikembangkan dengan tetap menggunakan intervensi logoterapi namun dengan variabel lain, seperti penerimaan diri (self-acceptance)terkait kondisi positif HIV. Selain itu, jumlah partisipan yang lebih banyak juga dapat diterapkan pada penelitian selanjutnya. Dengan adanya penelitian dengan menggunakan variabel lain dan jumlah partisipan penelitian yang lebih banyak, maka pengaplikasian logoterapi diharapkan dapat semakin meluas sehingga dapat bermanfaat untuk individu dalam jumlah yang lebih banyak pula.

Saran untuk pihak lain, khususnya pihak yayasan maupun lingkungan RW tempat tinggal para partisipan, akan lebih baik jika KDS (Kelompok Dukungan Sebaya) tetap dilakukan tanpa memerhatikan lamanya klien terdiagnosa positif HIV. Hal ini dikarenakan, KDS sangat penting bagi para ODHA tidak hanya sebagai sumber mendapatkan informasi baru saja, namun juga 
menjadi sumber dukungan ketika mereka sedang mengalami permasalahan terkait kondisi positif HIV saat ini.

Selain itu, baik yayasan maupun lingkungan RW dapat bekerjasama untuk melakukan kegiatan yang sesuai dengan minat para ODHA. Hal ini bertujuan agar mereka memiliki wadah untuk menyalurkan minat mereka sehingga kondisi positif HIV tidak mereka anggap sebagai keterbatasan mereka untuk tidak dapat melakukan sesuatu yang berguna. Seperti yang terlihat pada $\mathrm{W}$ dan $\mathrm{N}$, keduanya memiliki minat yang sama dan dapat dikembangkan oleh lingkungan sekitar, namun karena tidak mendukungnya fasilitas, minat tersebut tidak dapat tersalurkan. Sebagai tambahan, pihak keluarga lain yang memiliki anggota keluarga yang berstatus positif HIV disarankan untuk tidak bersikap diskriminatif dan tetap memberikan dukungan bagi mereka. Hal tersebut dikarenakan bentuk dukungan yang diterima oleh ODHA akan mampu menjadi penghalang munculnya keputusasaan dalam menjalani hidup.

Sementara itu, saran untuk para partisipan penelitian adalah terkait keteraturan dalam meminum obat. Seluruh partisipan memiliki riwayat tidak meminum obat sesuai dengan waktu yang telah ditentukan. Hal tersebut memiliki potensi membahayakan partisipan karena memiliki beberapa efek samping jika telat meminum obat sehingga perlu ditingkatkan ketaatan dalam meminum obat. Tidak hanya untuk menghindari efek samping dari telat meminum obat, hal ini juga menghindari partisipan masuk ke pengobatan lini dua yang diakibatkan oleh virus HIV yang sudah resisten dengan obat ARV lini satu karena ketidakteraturan minum obat.

\section{REFERENSI}

Anugerah, P. (2015, Desember 1). Data Kemenkes: ibu rumah tangga tertinggi HIV. Diambil tanggal $9016 \quad$ Juli 2016 dari http://www.bbc.com/indonesia/berita_indonesia/2015/12/151130_indonesia_hiv_iburumah tangga

Audet, C. M., Wagner, L. J., \& Wallston, K. A. (2015). Finding meaning in life while living with HIV: Validation of a novel HIV meaningfulness scale among HIV-infected participants living ini Tennessee. BioMed Central Psychology. 3 (15). 1-8.

Bastaman, H. D. (2007). Logoterapi: Psikologi untuk menemukan makna hidup dan meraih hidup bermakna. Jakarta: PT. RajaGrafindo Persada.

Carr, R. L., \& Gramling, L. F (2004). Stigma : A health barrier for women with HIV/AIDS. Journal of The Association of Nurses In AIDS Care 15 (5), 30 - 39.

Chandra, K. (2012). Efektivitas logoterapi pada perempuan lansia yang loneliness. (Tesis Magister Tidak Diterbitkan). Universitas Tarumanagara, Jakarta

Ditjen PP \& Kemenkes. (2014, September). Pusat data dan informasi Kementerian Kesehatan RI. Diambil tanggal $10 \quad$ Juli 2016 dari www.depkes.go.id/resources/download/pusdatin/infodatin/Infodatin\%20AIDS.pdf

Frankl, V. E. (1984). Man's Search for Meaning. New York, NY: Pocket Books

Madyan, A. S. (2009). AIDS dalam Islam: Krisis moral atau krisis kemanusiaan?. Bandung: PT. Mizan Pustaka

Shaughnessy, J. J., Zechmeister, E. B., \& Zechmeister, J. S. (2015). Research methods in psychology (10th ed.). New York, NY: McGraw Hill Education.

Suyasa, P. T. Y. S. (2008, June). The measurement of meaning in life. Paper presented at the Second Asian Psychological Association(APsyA), Kuala Lumpur, Malaysia, Full paper retrieved fromhttps://goo.gl/5vmseg.

Triwardhany, R. (2015). Penerapan logoterapi untuk self-esteem pria HIV. (Tesis Magister Tidak Diterbitkan). Universitas Tarumanagara, Jakarta. 
(Studi pada Wanita Dewasa Awal yang Terdiagnosa HIV karena Tertular Suami)

Vance, R., \& Denham, S. (2008). HIV/AIDS related stigma: Delivering appropriate nursing care. Teaching and Learning in Nursing 3, 59-66.

Yayasan Spiritia. (2003). Hidup dengan HIV/AIDS. Jakarta: Yayasan Spiritia. . (2015, Januari 25). Lembaran informasi tentang HIV dan AIDS untuk orang yang hidup dengan HIV (ODHA). Diambil tanggal 9 Juli 2016, dari http://spiritia.or.id/li/bacali.php?lino=001. 